\title{
Effect of No-tillage System and Fertilization on Wheat Production
}

\author{
Mircea Adrian GRIGORAS ${ }^{1}$, Agatha POPESCU², Ioan NEGRUTIU³ \\ Mihai GIDEA², Ioan $\mathrm{HAS}^{4}$, Doru PAMFIL ${ }^{*}$ \\ ${ }^{1}$ University of Agricultural Sciences and Veterinary Medicine, 3-5 Manastur Street, 400372 Cluj- \\ Napoca,Romania; dpamfil@usamvcluj.ro ("correspondingauthor) \\ ${ }^{2}$ University of Agricultural Sciences and Veterinary Medicine Bucharest, 59 Marasti Street, District 1, 011464 Bucharest, Romania \\ ${ }^{3}$ Ecole Normale Superieure de Lyon, Institut 'Michel Serres', 15 parvis René Descartes - BP 700069342 Lyon Cedex 07, France \\ ${ }^{4}$ Agricultural Research and Development Station Turda, 27 Agriculture Street, Turda, 40100, Cluj County, Romania
}

\begin{abstract}
Conservation agriculture is an alternative to conventional agriculture and one of the most efficient systems for sustainable agricultural development, stimulating soil biological activity, increasing organic matter and humus content. In order to evaluate the impact of the conservation agriculture system compared to the conventional agriculture system on wheat yield, a bi-factorial experiment on wheat crop based on split-plot model was organized in the Transylvania Plain, Romania, where there are a few research results in the field and the area has a high potential for the implementation of conservation agriculture system. First factor ('A') was agriculture system, having two levels: 'A1' tillage (classic) system and 'A2' no-tillage system, and the second, 'B' factor was fertilization, with three levels: 'B1' no fertilization, ' $\mathrm{B} 2$ '- $\mathrm{N}_{80} \mathrm{P}_{40} \mathrm{~kg} / \mathrm{ha}$, which is the average level practiced by farmers in the area and ' $\mathrm{B} 3$ '- $\mathrm{N}_{150} \mathrm{P}_{75} \mathrm{~kg} / \mathrm{ha}$, which is the recommended level for obtaining a high production performance specific to 'Ariesan' wheat cultivar used in this experiment. The results pointed out that, in comparison with conventional agriculture, the application of no-tillage system determined a lower wheat yield by $353 \mathrm{~kg}$ per surface unit. Fertilization assured a significant increase by $610 \mathrm{~kg}$ wheat grains per ha. In the case of the conservation agriculture system, the highest production gain was $1,260 \mathrm{~kg} / \mathrm{ha}$ for 'B3A2' level compared to 'B1A2' level, where the highest fertilization level was applied. The lowest production gain was $410 \mathrm{~kg} / \mathrm{ha}$ registered by 'B3A1-B1Al' which was the highest fertilizer dose in case of conventional agriculture. In conclusion, the application of no-tillage system increased the efficiency of fertilization in terms of wheat yield compared to the classical agriculture. As a result, it is recommended as farmers dealing with wheat cropping in the area and also in other regions with similar soil and climate conditions to implement conservation agriculture.
\end{abstract}

Keywords: conservation tillage, fertilization levels, wheat yield

\section{Introduction}

Conservation agriculture is a part of sustainable agriculture, aiming at optimizing yields and profits but also at protecting land resources and the environment. Conservation agriculture involves zero or minimum soil disturbance through tillage (no-tillage, reduced tillage, mulch tillage and strip-tillage), a balanced use of fertilizers and herbicides, a permanent soil biomass cover enhancing water and soil conservation, crop rotation and integrated pest management, reduced production costs and increased farming efficiency (Derpsch, 2008; Dumanski et al., 2006; Koepke, 2003; Koller, 2003).

The lower productivity induced by the use of a conservation agriculture system could be balanced by using fertilizers and herbicides (Feiza et al., 2003).

Due to its advantages, conservation agriculture has become a common practice on about 100 million ha in South and North America, Europe, Asia and Africa. No tillage farming has become a current practice in countries such as: USA, Brazil, Argentina, Australia, Canada, Mexico (Sarpe, 2008).

In Europe, reduced tillage is more common than notillage and it is used in order to mitigate soil erosion and assure reduced costs in machinery, fuel and labour saving in Norway, Germany, Netherlands, etc. The controversial opinion existing in Europe about the implementation of conservation agriculture is due to the progress registered in the development of integrated agriculture system (IAS), which aims to maximize farmers' income by reducing farm inputs (fertilizers, herbicides, etc.) to the EU (Koller, 2003; Lahmar, 2009). However, conservation agriculture is seen as a part of the food agri practices and agri-environmental measures (Bilalis et al., 2011).

During the transition to conservation agriculture benefic effects were noticed on cereal growth, soil N, physical properties, moisture and organic matter (Gruber et al., 2011; Lopez et al., 2012; Lopez-Fando et al., 2012; Pietola et al., 2003; Melero et al., 2011). 
In Romania, no tillage or reduced tillage is used as a mean to diminish costs, and improve soil structure and maintain environment quality (Rusu et al., 2011). These systems were tested in a few agricultural research stations and farms mainly for wheat, maize, soybean and other important crops in Romania, assessing the impact of no tillage or minimum tillage on crop yield, grain quality, soil properties, water permeability, carbon sequestration (Grigoras et al., 2011; 2012).

In this context, the paper purpose was to study the impact of tillage system and fertilization on winter wheat crop under the conditions of the Transylvanian Plain, Romania, where farmers need alternatives for agriculture system and fertilizer amount per surface unit in order to increase wheat production. The results should be available for any other farmers who are dealing with wheat cropping in similar climate and soil conditions.

\section{Materials and methods}

\section{Biological material}

The experiments employed winter wheat as biological material, namely the 'Ariesan' cultivar that is largely spread in agricultural farms of the Transylvania area. The dose of seed used per ha was $245 \mathrm{~kg}$. Solely certified seeds were used, treated with the amount of 2 liters/ton insecticidefungicide which contains imidacloprid $233 \mathrm{~g} / \mathrm{l}$ and tebuconazol $13 \mathrm{~g} / \mathrm{l}$. The 'Ariesan' cultivar has a high production potential assuring 550 germinable grains per square meter.

\section{Study site}

The experiments have been carried out at the Agriculture Research and Development Station Turda, Cluj County, in the central part of Romania, situated at $46^{\circ} 35$ 'North latitude, $23^{\circ} 47$ 'East longitude and $427 \mathrm{~m}$ altitude.

\section{Climate and soil conditions}

According to the Turda Meteorological Station, the average temperature in the area was ranging between $3.7^{\circ} \mathrm{C}$ in January 2011 and $20.7^{\circ} \mathrm{C}$ in July 2011, considered a normal temperature for winter and a high temperature for the summer season.

The average rainfalls varied between $172.6 \mathrm{~mm}$ in June (an excessively rainy month) to $3.4 \mathrm{~mm}$ in September 2011 (an excessively droughty month).

The soil where the experiments were carried out was of a brown reddish type characterized by $5.2 \mathrm{pH}$ and $3.8 \%$ humus content.

\section{Methodological aspects}

Based on a split-plot model, the experiments were organized on the surface of 12,000 square meters divided into 4 large plots (4 repetitions) each one of 3,000 square metres. Each large plot was divided into other two sub plots of 1,500 square metres each. Each sub-plot was divided into three split small plots each one having 500 square metres.

The bi-factorial analysis of variance (ANOVA) was used as follows: 'A' factor-agricultural system with $2 \mathrm{lev}$ - els: 'A1'-tillage and 'A2'-no-tillage; 'B' factor-fertilization with 3 levels: 'B1'-unfertilized land, control variant, 'B2'fertilization $\mathrm{N}_{80} \mathrm{P}_{40} \mathrm{~kg} / \mathrm{ha}$, which is the average fertilizer amount used by farmers in the area according to National Institute for Statistics, and 'B3'-fertilization $\mathrm{N}_{150} \mathrm{P}_{75} \mathrm{~kg} / \mathrm{ha}$, which is the optimum level recommended to be applied by farmers in order to carry out a high wheat yield specific to 'Ariesan'cultivar (Rusu et al.,2005).

The resulted data were statistically processed using variance analysis, $\mathrm{F}$ test and LSD (Least Significant Difference) test, which are commonly utilized in the multicriterial statistical analysis.

The mathematical formula used in such a case was: $\eta_{i}$ $=\mu+\alpha_{i}+\beta_{i}+\gamma_{i j}$ where: $\eta_{i j}$ was the average of the observed variables corresponding to $i$ and $j$ cells of ANOVA model, $\mu$-general average, $\alpha_{i}$ and $\beta_{i}$ are the effects of $A$ and $B$ factors, $\gamma_{i j}$ was the interaction between various levels of $A$ and $\mathrm{B}$ factors.

\section{Technological aspects}

The conventional agriculture system applied consisted of: ploughing, harrowing, sowing, harvesting and conservation no-tillage system and was characterized by direct seeding with direct drilling machine.

Weed control was uniformly carried out on the whole experimental surface, by means of a pre-emergence treatment with 2 liters/ha herbicide (glifosat $360 \mathrm{~g} / \mathrm{l}$ ) and postemergence treatment with $20 \mathrm{~g} / \mathrm{ha}$ (tribenuron metil).

For the both agricultural systems, harvesting was performed with the harvester specific for experimental fields.

\section{Results and discussion} yield

\section{The influence of agriculture system ('A'factor) on wheat}

In the case of the classical tillage system the average production obtained was $2,526.7 \mathrm{~kg} / \mathrm{ha}$ and for the notillage conservation system it was $2,173 \mathrm{~kg} / \mathrm{ha}$. The difference of $353.4 \mathrm{~kg} / \mathrm{ha}$ proved that conventional system recorded a higher production compared to the performance level registered by the no tillage system.

However, between the average values of the obtained productions under the influence of the two agriculture systems there are no significant differences. But the existing difference between the two agriculture systems is explained by the increased apparent density, the reduced soil porosity due to the increased weeding potential.

The influence of 'B' factor - fertilization level on wheat yield for the same level of 'A' factor - tillage

\section{The influence of ' $B$ ' factor-fertilization on wheat yield} obtained in conventional agriculture system, 'AI'

For the tillage system of agriculture, wheat yield increased from $1,780 \mathrm{~kg} / \mathrm{ha}$ for 'B1' -unfertilized land to $3,190 \mathrm{~kg} / \mathrm{ha}$ for 'B3', where the highest amount of fertilizer was applied, $\mathrm{N}_{150} \mathrm{P}_{75} \mathrm{~kg} / \mathrm{ha}$. Yield gains due to fertilization level have been $46.6 \%$ for 'B2' and $79.2 \%$ for 'B3' (Tab. 1). 
Tab. 1. The influence of agriculture system ('A' factor) on wheat yield

\begin{tabular}{|c|c|c|c|c|c|c|}
\hline A factor & 'B' factor & $\begin{array}{l}\text { Wheat yield- } \\
\text { (kg/ha) }\end{array}$ & $\begin{array}{c}\text { Differences } \\
(\mathrm{kg} / \mathrm{ha})\end{array}$ & Significance & Average 'A' & $\begin{array}{c}\text { Differences } \\
(\mathrm{kg} / \mathrm{ha})\end{array}$ \\
\hline \multirow{3}{*}{$\begin{array}{l}\text { 'Al' - Conventional } \\
\text { agriculture system }\end{array}$} & 'B1' & 1,780 & 0 & - & \multirow{3}{*}{2,526} & \multirow{3}{*}{ Control } \\
\hline & 'B2' & 2,610 & 830 & $\mathrm{xxx}$ & & \\
\hline & 'B3' & 3,190 & 1,410 & $\mathrm{xxx}$ & & \\
\hline \multirow{3}{*}{$\begin{array}{l}\text { 'A2' - Conservation } \\
\text { agriculture system }\end{array}$} & 'B1' & 1,550 & 0 & - & \multirow{3}{*}{2,173} & \multirow{3}{*}{-353} \\
\hline & 'B2' & 2,160 & 610 & $\mathrm{xxx}$ & & \\
\hline & 'B3' & 2,810 & 1,260 & $\mathrm{xxx}$ & & \\
\hline LSD 5\% & & & 117.5 & & & 225.8 \\
\hline LSD 1\% & & & 188.0 & & & 388.0 \\
\hline LSD $0.1 \%$ & & & 258.5 & & & 512.1 \\
\hline
\end{tabular}

LSD - Least Significant Difference

Influence of ' $B$ ' factor - fertilization on wheat yield obtained in conservation agriculture system, 'A2'

In the no-tillage system of agriculture, the wheat yield also increased in accordance to fertilization level from $1,550 \mathrm{~kg} / \mathrm{ha}$ in case of 'B1'-unfertilized land to $2,810 \mathrm{~kg} / \mathrm{ha}$ for ' $\mathrm{B} 3$ ' $-\mathrm{N}_{150} \mathrm{P}_{75} \mathrm{~kg} / \mathrm{ha}$. The yield gains due to the amount of fertilizer applied varied between $610 \mathrm{~kg} / \mathrm{ha}$ (39.3\%) for 'B2' and 1,260 kg/ha (81.2\%) in case of 'B3'.

For each fertilization level, the differences of yield gains are: $-230 \mathrm{~kg} / \mathrm{ha}$ for ' $\mathrm{B} 1^{\prime}$ '-unfertilized land, $-450 \mathrm{~kg} / \mathrm{ha}$ for 'B2'- $\mathrm{N}_{80} \mathrm{P}_{40} \mathrm{~kg} / \mathrm{ha}$ and $-380 \mathrm{~kg} / \mathrm{ha}$ for ' $\mathrm{B} 3$ ' $-\mathrm{N}_{150} \mathrm{P}_{75} \mathrm{~kg} / \mathrm{ha}$ fertilization. Conservation agriculture determined a reduction of wheat yield ranking between $17.3 \%$ in case of 'B2' and $11.9 \%$ in case of 'B3' (Tab.1).

\section{The influence of fertilization level 'B' Factor on wheat yield}

In the case of 'B1', the control variant, unfertilized land, the average wheat yield was $1,665 \mathrm{~kg} / \mathrm{ha}$. The 'B2' variant, where the fertilization level was $\mathrm{N}_{80} \mathrm{P}_{40}$ registered 2,385 $\mathrm{kg} / \mathrm{ha}$ and the 'B3' variant with the highest fertilizer dose $\mathrm{N}_{150} \mathrm{P}_{75}$ performed 3,000 kg/ha. Therefore, the higher the fertilization level, the higher the wheat yield (Tab. 2).

Analyzing the influence of fertilization level on wheat production it was noticed that the additional amount of fertilizer has determined a very significant increase of the production obtained in comparison with the unfertilized land (Ibragimov et al., 2012; Gao et al., 2009).
Influence of agriculture system-A factor on wheat yield for the same fertilization level-B factor

For the control variant (unfertilized), wheat yield was $1,780 \mathrm{~kg} / \mathrm{ha}$ in case of conventional agriculture and 1,550 $\mathrm{kg} / \mathrm{ha}$ in case of conservation agriculture. Therefore, notillage system determined a reduced wheat yield by $12.2 \%$. For 'B2' where $\mathrm{N}_{80} \mathrm{P}_{40} \mathrm{~kg}$ fertilization level was applied per surface unit, wheat yield registered $2,610 \mathrm{~kg} / \mathrm{ha}$ in case of conventional agriculture and $450 \mathrm{~kg} / \mathrm{ha}$ less in case of conservation agriculture, that is $2,160 \mathrm{~kg} / \mathrm{ha}$ (Fig.1.). In this case, no-tillage system determined a yield reduced by $17.3 \%$. For 'B3' level, wheat yield recorded $3,190 \mathrm{~kg} / \mathrm{ha}$ in case of 'A1'-conventional agriculture system and 2,810 $\mathrm{kg} / \mathrm{ha}$ by $380 \mathrm{~kg}$ less for 'A2'-conservation agriculture system. Wheat yield was $12 \%$ lower for 'A2'. Therefore, the conventional agriculture system determined higher wheat production performance compared to conservation agriculture for the same fertilization level (Tab. 2).

The analysis of the data from Tab. 2. regarding the influence of the agriculture system on wheat production revealed that for all the fertilization levels conservation agriculture system has determined a lower production. This was due to the fact that sowing directly into the ground required by conservation agriculture has led to a higher apparent soil density than in the classical tillage system. As a consequence, soil porosity and its capacity of mineralization of the applied fertilizer has been diminished (Dormaeer, 1990).

Tab.2. Influence of fertilization 'B' factor on wheat yield

\begin{tabular}{|c|c|c|c|c|c|}
\hline 'B' factor & 'A' factor & Wheat yield $(\mathrm{kg} / \mathrm{ha})$ & Differences $(\mathrm{kg} / \mathrm{ha})$ & Average 'B' factor & Difference $(\mathrm{kg} / \mathrm{ha})$ \\
\hline \multirow{2}{*}{ 'B1' unfertilized } & 'Al' & 1,780 & 0 & \multirow{2}{*}{1,665} & \multirow{2}{*}{ Control } \\
\hline & 'A2' & 1,550 & -230 & & \\
\hline \multirow{2}{*}{ 'B2' $\mathrm{N}_{80} \mathrm{P}_{40} \mathrm{~kg} / \mathrm{ha}$} & 'Al' & 2,610 & 0 & \multirow{2}{*}{2,385} & \multirow{2}{*}{720} \\
\hline & 'A2' & 2,160 & -450 & & \\
\hline \multirow{2}{*}{ 'B3’ $\mathrm{N}_{150} \mathrm{P}_{75} \mathrm{~kg} / \mathrm{ha}$} & 'Al' & 3,190 & 0 & \multirow{2}{*}{3,000} & \multirow{2}{*}{1,335} \\
\hline & 'A2' & 2,810 & -380 & & \\
\hline LSD $5 \%$ & & 192.1 & & & 126.0 \\
\hline LSD 1\% & & 2917 & & & 213.8 \\
\hline LSD $0.1 \%$ & & 412.6 & & & 283.2 \\
\hline
\end{tabular}

LSD - Least Significant Difference 


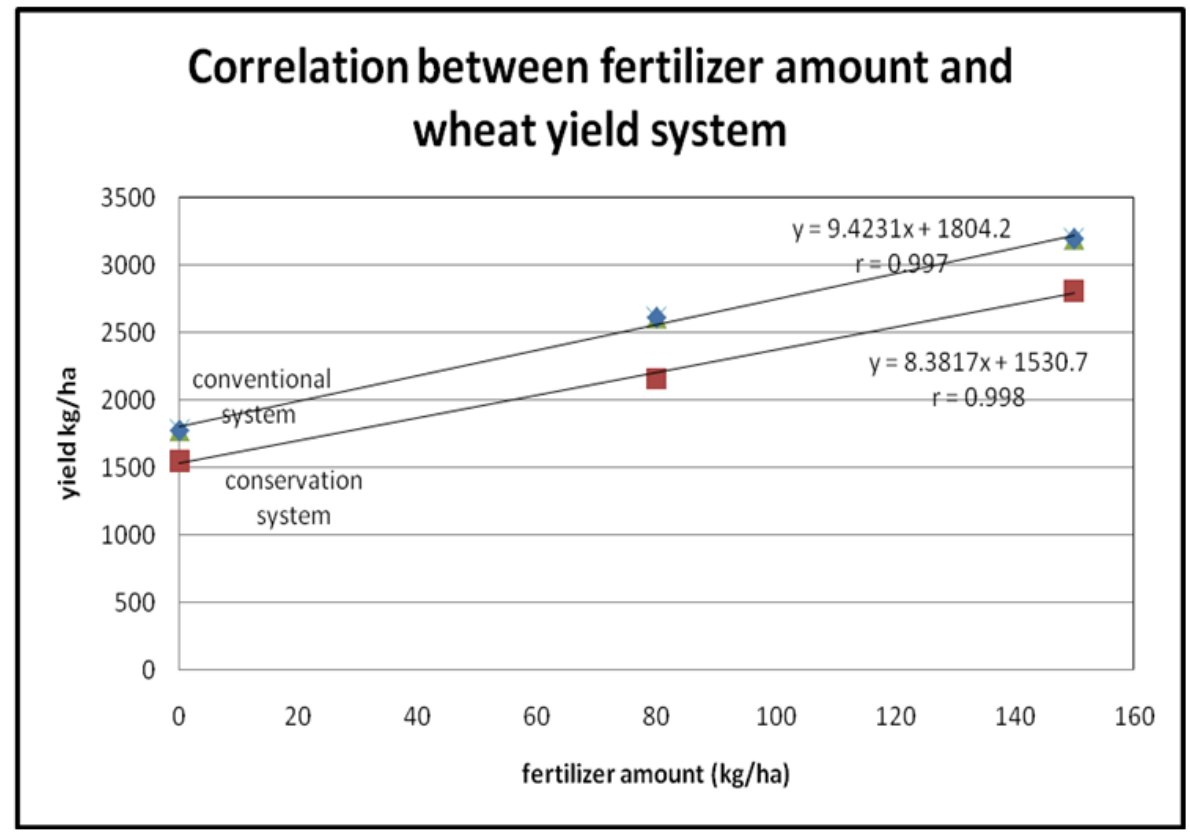

Fig.1. Correlation between fertilizer amount and wheat yield

In addition, the reduced soil permeability has determined a weak water penetration into the soil and a weak capacity to levigate fertilizer at roots level (Cassman $e t$ al., 2002). Despite that, the effect of the fertilizer was noticed from a growing season to another, and it was lower and lower.

Analyzing the influence of fertilization on wheat yield, it was noticed that in the case of both agriculture systems an increased fertilization level has determined a significant production gain (Mustatea et al., 2009; Voica, 2009). No significant differences regarding wheat production were also reported by Iqbal et al. (2005), De Vita et al. (2007), Gursoy et al. (2010), Huang et al. (2012).

From Fig. 1 can notice that for the both tillage systems there is a high correlation between the fertilizer amount and wheat yield, the correlation factor being $\mathrm{r}=0.99$. Therefore, conservation system in its variant no-tillage could be used by farmers in order to obtain the same production performance and also a good impact on soil activity, organic matter, humus content and moisture.

\section{Conclusions}

The increased fertilization determined a significant yield gain, $+610 \mathrm{~kg} / \mathrm{ha}$ for ' $\mathrm{B} 2$ ' $\mathrm{N}_{80} \mathrm{P}_{40}$ and $+1,260 \mathrm{~kg} / \mathrm{ha}$ for ' ${ }^{3} 3$ ' $\mathrm{N}_{150} \mathrm{P}_{75}$. Therefore, the higher the amount of fertilizer applied, the higher the wheat production per surface unit. Compared to conventional agriculture, no-tillage conservation system determined a significant reduction of wheat yield accounting for $-353 \mathrm{~kg} / \mathrm{ha}$. Analyzing the situation according to fertilization level, the conservation agriculture system determined the decrease of wheat yield by $230 \mathrm{~kg} / \mathrm{ha}$ for 'B1'-unfertilized, by $450 \mathrm{~kg} / \mathrm{ha}$ for 'B2' $\mathrm{N}_{80} \mathrm{P}_{40}$ and by $380 \mathrm{~kg} / \mathrm{ha}$ for ' $\mathrm{B} 3$ ' $\mathrm{N}_{150} \mathrm{P}_{75}$. In case of the conservation agriculture system, the highest production gain was $1,260 \mathrm{~kg} / \mathrm{la}$ for 'B3A2' compared to 'B1A2', that is for the highest fertilization level. The lowest production gain was $410 \mathrm{~kg} / \mathrm{ha}$ registered by 'B3A1-B1A1' which is the highest fertilization dose in case of conventional agriculture. The yield differences determined by the dose of fertilizer applied are statistically assured.

As a conclusion for practice, farmers could apply no tillage system but they have to pay attention to fertilization level in order to sustain wheat productivity. The amount of fertilizer has to be determined according to the soil content in nutrients, plant need and crop rotation. Under an insufficient water supply, conservation agriculture has determined a lower wheat yield in comparison with conventional agriculture. This was due to the increase of soil apparent density, the reduction of soil permeability and the decline of soil capacity to levigate fertilizers at the level of plant roots. But this decline of production was not statistically ensured.

Therefore, conservation agriculture could be successfully implemented in wheat cropping in the Transylvanian Plain but also in any other regions where climate and soil conditions are similar.

\section{Acknowledgements}

All the support given by Executive Unit for Research, Development and Innovation Financing in Higher Education (UEFISCDI) for financing the PN II Project 52-179, in order to carry out the experiments and set up this paper is gratefully acknowledged. 


\section{References}

Bilalis D, Karkanis A, Patsiali S, Agriogianni M, Konstants A, Triantafyllidis V (2011). Performance of wheat varieties (Triticum aestivum L.) under conservation tillage practices in organic agriculture. Not Bot Horti Agrobo 39(2):28-33.

Cassman KG, Dobermann AR, Walters DT (2002). Agroecosystems, nitrogen use efficiency and nitrogen management. Ambio 31(2):132-140.

De Vita P, Di Paolo E, Fecondo G, Di Fonzo N, Pisante M (2007). No-tillage and conventional tillage effects on durum wheat yield, grain quality ans soil moisture content in southern Italy. Soil and Tillage Res 92(1-2):69-78.

Derpsh R (2008). No-tillage and conservation agriculture. A progress raport. In: Goddard, T, Zoebisch MA, Gen YT, Ellis W, Watson A, Soubatpenit S (Eds.). No-till farming systems. Special publication No. 3, World Association of Soil and Water Conservation, Bangkok, 60-1:544.

Dormaeer JF (1990). Effcet of active roots on the decomposition of soil organic materials. Biol Fertil Soils 10(2):121-126.

Dumanski J, Peiretti R, Benites JR, McGarry D, Pieri C (2006). The paradigm of conservation tillage. Proc World Association for Soil and Water Conservation 7:58-64.

Feiza V, Feiziene D, Riley HCF (2003). Soil available P and P oftake responses to ifferent tillage and fertilization systems in the hily morainic landscape of western Lithuania. Soil and Tillage Res 74(1):3-14.

Gao Y, Li Y, Zhang J, Liu W, Dang Z, Cao W, Qiang Q (2009). Effects of mulch, $\mathrm{N}$ fertilizer and plant density on wheat yield, wheat nitrogen uptake and residual soil nitrate in a dryland area of China. Nutrient Cycling Agroecosyst 85(2):109-121.

Grigoras MA, Popescu A, Pamfil D, Has I, Cota LC (2011). Effect of conservation agriculture on maize yield in the Transilvanian Plain, Romania. Procof International Conference on Agricultural and Biosystems Engineering, NH Naarden, Amsterdam,WASET. World Acad Sci, Engin Technol 78:224-233.

Grigoras MA, Popescu A, Pamfil D, Has I, Gidea M (2012). Conservation agriculture versus conventional agriculture: The Influence of Agriculture System, Fertilization and Plant Protection on Wheat Yield. Not Bot Horti Agrobo 40(1):188-194.

Grigoras MA, Popescu A, Pamfil D, Has I, Gidea M (2012). Influence of no-tillage agriculture system and fertilization on wheat yield and grain protein and gluten contents. JFAE 10(2):532-539.

Gruber S, Mohring J, Claupein W (2011). On the way towards conservation tillage-soil moisture and mineral nitrogen in a long-term field experiment in Germany. Soil and Tillage Res 115-116:80-87.

Gursoy S, Sessiz A, Malhi SS (2010). Short-term effects of tillage and residue management following cotton on grain yield and quality of wheat. Field Crop Res 119(2-3):260-268.
Huang G, Chai Q, Feng F, Yu A (2012). Effects of different tillage systems on soil properties, root growth, grain yield and water use efficiency of winter wheat (Triticum aestivum L.) in Arid Northwest China. J Integrative Agric 11(8):12861296.

Ibragimov N, Djumaniyazova Y, Ruzimov J, Eshchnov R, Sheer C, Kienzler K, Lamers JPA, Bekchnov M (2012). Optimal irrigation and $\mathrm{N}$-fertilizer management for sustainable winter wheat production in Khorezm, Uzbekistan. Cotton, Water, Salts and Soums 171-180 p.

Iqbal MM, Akhtr J, Mohammad W, Shah SM, Nawaz H, Mah$\operatorname{mood} \mathrm{K}(2005)$. Effect of tillage and fertilizer levels on wheat yield, nitrogen uptake and their correlation with carbon isotope discrimination under rainfed conditions in north-west Pakistan. Soil and Tillage Res 80(1-2):47-57.

Koepke U (2003). Conservation agriculture with and without use of agrochemicals, Proc of the $2^{\text {nd }}$ World Congress on Conservation Agriculture, Iguassu Falls, Parana, Brazil. In: Peigne J, Aveline A, Cabbavaciuolo M, Giteau JL, Gautronneau Y 2007. Soil structure and earth worm activity under different tillage systems in organic farming.

Koller I (2003). Techniques of soil tillage 1-25 p. In: Adel El Titi (Ed.). Soil tillage in agroecosystems, CRC Press, Boca Raton.

Lahmar R (2009). Adoption of conservation agriculture in Europe. Lessons from the KASSA Project. www.esw.wur.nl

Lopez MV, Blanco-Moure N, Angeles Limon N, Gracia R (2012). No tillage in rainfed Aragon (NE Spain): Effect on organic carbon in the soil surface horizon. Soil and Tillage Res 118:61-65.

Lopez-Fando C, Pardo MT (2012). Use of a partial width-tillage systems maintains benefits of no-tillage in increasing total soil nitrogen. Soil and Tillage Res 118:32-39.

Melero S, Lopez-Belido RJ, Lopez-Bellido L, Mufioz-Romero V, Moreno F, Murillo JM (2011). Long-term effect of tillage, rotation and nitrogen fertiliser on soil quality in a Mediterranean vertisol. Soil and Tillage Res 114(2):97-107.

Mustatea P, Saulescu NN, Ittu G, Paunescu G, Voinea L, Stere I, Mirlogeanu S, Constantinescu E, Nastase D (2009). Grain yield and yield stability of winter wheat cultivars in contrasting weather conditions. Ro Agric Res 76:5-15

Romania's Statistical Yearbook (2010). www.insse.ro

Rusu T, Moraru PI, Rotar I (2011). Effect of soil tillage system on soil properties and yield in some arable crops. JFAE 9(34):426-429.

Rusu M, Marghitas M, Oroian I, Mihaescu T, Dumitras A (2005). Treatise of Agro-chemistry, Ceres Press House, Bucharest, $688 \mathrm{p}$.

Sarpe N (2008). 40 years of research regarding the no-tillage system in maize under Romania conditions. Ann ANRDI Fundulea 76:113-131.

Voica M (2009). Yield stability of new winter wheat and Triticale varieties at ARDS Pitesti Albota. Ro Agric Res 76:1323. 